Babelyuk Valeriy Y., Tserkovniuk Ruslan G., Dubkova Galyna I., Kruhliy Yuriy Z., Korolyshyn Tetyana A., Babelyuk Nazariy V., Zukow Walery, Ruzhylo Sofiya V., Fihura Oksana A., Gozhenko Anatoliy I., Popovych Igor L. Relationships between the neuroendocrine parameters and virtual chakras energy and asymmetry. Journal of Education, Health and Sport. 2022;12(1):235-249. eISSN 2391-8306. DOI http://dx.doi.org/10.12775/JEHS.2022.12.01.020

https://apcz.umk.pl/JEHS/article/view/JEHS.2022.12.01.020

https://zenodo.org/record/5888096

The journal has had 40 points in Ministry of Education and Science of Poland parametric evaluation. Annex to the announcement of the Minister of Education and Science of December 1, 2021. No. 32343 . Has a Journal's Unique Identifier: 201159. Scientific disciplines assigned: Physical Culture Sciences (Field of Medical sciences and health sciences); Health Sciences (Field of Medical Sciences and Health Sciences).

Punkty Ministerialne z 2019 - aktualny rok 40 punktów. Zalącznik do komunikatu Ministra Edukacji i Nauki z dnia 1 grudnia 2021 r. Lp. 32343. Posiada Unikatowy Identyfikator Czasopisma: 201159. Przypisane dyscypliny naukowe:Nauki o kulturze fizycznej (Dziedzina nauk medycznych i nauk o zdrowiu); Nauki o zdrowiu (Dziedzina nauk medycznych i nauk o zdrowiu).

(1) The Authors 2022;

This article is published with open access at Licensee Open Journal Systems of Nicolaus Copernicus University in Torun, Poland

Open Access. This article is distributed under the terms of the Creative Commons Attribution Noncommercial License which permits any noncommercial use, distribution, and reproduction in any medium, provided the original author (s) and source are credited. This is an open access article licensed under the terms of the Creative Commons Attribution Non commercial license Share alike The authors declare that there is no conflict of interests regarding the publication of this paper.

Received: 02.01.2022. Revised: 17.01.2022. Accepted: 21.01.2022.

\title{
RELATIONSHIPS BETWEEN THE NEURO-ENDOCRINE PARAMETERS AND VIRTUAL CHAKRAS ENERGY AND ASYMMETRY
}

\author{
Valeriy Y. Babelyuk ${ }^{1,2}$, Ruslan G. Tserkovniuk ${ }^{1}$, Galyna I. Dubkova ${ }^{2}$, Yuriy Z. Kruhliy ${ }^{1}$, \\ Tetyana A. Korolyshyn ${ }^{1,2,5}$, Nazariy V. Babelyuk ${ }^{2}$, Walery Zukow ${ }^{3}$, Sofiya V. Ruzhylo ${ }^{4}$, \\ Oksana A. Fihura ${ }^{4}$, Anatoliy I. Gozhenko ${ }^{1}$, Igor L. Popovych ${ }^{1,5}$ \\ ${ }^{1}$ Ukrainian Scientific Research Institute of Medicine for Transport MHU, Odesa, \\ Ukraine valeriybabelyk64@gmail.com prof.gozhenko@gmail.com \\ ${ }^{2}$ Clinical Sanatorium „Moldova”, Truskavets', Ukraine dubkovahalyna@gmail.com \\ ${ }^{3}$ Nicolaus Copernicus University, Torun, Poland w.zukow@wp.pl \\ ${ }^{4}$ Ivan Franko Pedagogical University, Drohobych, Ukraine doctor-0701@ukr.net \\ ${ }^{5}$ OO Bohomolets' Institute of Physiology NAS, Kyïv, Ukraine i.popovych@biph.kiev.ua
}

\begin{abstract}
Background. Earlier, we found a close correlation between EEG and gas-discharge image (GDI) parameters. The aim of this study is to analyze the relationship of EEG parameters with the energy and asymmetry of virtual chakras, reconstructed on the basis of GDI parameters. Material and Methods. We observed twice 31 women and 29 men aged 26-76 years with dysfunction of neuroendocrine-immune complex. In the morning in basal conditions at first registered GDI by the method of GDV by the device "GDV Chamber" ("Biotechprogress", $\mathrm{SPb}, \mathrm{RF}$ ). Than we registered EEG. Results processed by method of canonical analysis, using the software package "Statistica 64". Results. The coefficients of canonical correlation

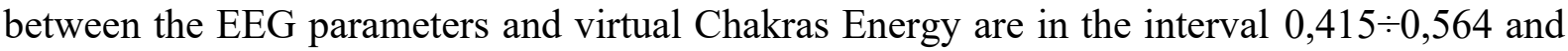
$0,358 \div 0,528$ when registering without a filter and with a filter, respectively. Additional inclusion of HRV and endocrine parameters increases the strength of the canonical correlation to 0,768 and 0,772 , respectively. The coefficients of canonical correlation between the EEG parameters and individual virtual Chakras Asymmetry are in the interval $0,284 \div 0,634$ and $0,152 \div 0,458$ when registering without a filter and with a filter, respectively. Integral coefficient of the canonical correlation is 0,820 . Conclusion. The above data, taken together with the previous ones, state that between parameters of neuroendocrine-immune complex and GDV exist strong canonical correlation suggesting suitability of the latter method.
\end{abstract}

Key words: Gas Discharge Visualization, virtual Chakras, EEG, relationships.

\section{INTRODUCTION}


According to Ayurvedic medicine, Chakras are power centers, related to the endocrine glands and neural plexus as well as to some organs. Chase CR [9] provides a table according to which the first Chakra is associated with adrenals, pelvic nerve plexus, spine, kidneys, bladder, large intestine; second Chakra with testes/ovaries, inferior mesenteric ganglion, ileum, organs of reproduction; third Chakra with [endocrine] pancreas, celiac plexus ganglion, liver, gall bladder, stomach, duodenum, pancreas, spleen; fourth Chakra with thymus, celiac plexus, heart, circulation, vagus nerve; fifth Chakra with thyroid and parathyroid glands, inferior cervical ganglion, lungs, bronchus, larynx, pharynx, large intestine, vagus nerve; sixth Chakra with pituitary and pineal glands, thalamus, hypothalamus, superior cervical ganglion, left brain, lower brain, ears/nose, left eye; seventh Chakra with pineal gland, right brain, upper brain, right eye. Korotkov KG [12] put forward the concept that each Chakra is associated with a part of the finger. This approach is embodied in the "GDV Chakras" program, which allows us to quantify the state of virtual Chakras.

Earlier, we found a close correlation between EEG and gas-discharge image (GDI) parameters [6]. The aim of this study is to analyze the relationship of EEG parameters with the energy and asymmetry of virtual chakras, reconstructed on the basis of GDI parameters

\section{MATERIAL AND METHODS}

The object of observation were 60 volunteers: 31 women and 29 men aged 26-76 years with dysfunction of neuro-endocrine-immune complex and dysmetabolism.

In the morning we registered the GDI (Dubkova GI) by the method of GDV by the device of "GDV Chamber" ("Biotechprogress", SPb, RF). The first base parameter of GDV is Area of GDI in Right, Frontal and Left projections registered both with and without polyethylene filter. The second base parameter is a coefficient of Shape. The third base parameter of GDI is Entropy. Program estimates also Energy and Asymmetry of virtual Chakras [11-13]. Than EEG recorded (TA Korolyshyn) a hardware-software complex "NeuroCom Standard" (KhAI MEDICA, Kharkiv) monopolar in 16 loci (Fp1, Fp2, F3, F4, F7, F8, C3, C4, T3, T4, P3, P4, T5, T6, O1, O2) by 10-20 international system, with the reference electrodes A and Ref tassels on the ears. The duration of the epoch was $25 \mathrm{sec}$. Among the options considered the average EEG amplitude $(\mu \mathrm{V})$, average frequency $(\mathrm{Hz})$, frequency deviation $(\mathrm{Hz})$, index $(\%)$ as well as absolute $\left(\mu \mathrm{V}^{2} / \mathrm{Hz}\right)$ and relative (\%) power spectrum density (PSD) of basic rhythms: $\beta(35 \div 13 \mathrm{~Hz}), \alpha(13 \div 8 \mathrm{~Hz}), \theta(8 \div 4 \mathrm{~Hz})$ and $\delta(4 \div 0,5 \mathrm{~Hz})$ in all loci, according to the instructions of the device. In addition, calculated coefficient of Asymmetry (As) and Laterality Index (LI) for PSD each Rhythm using formulas:

As, $\%=100 \bullet($ Max - Min $) /$ Min; LI, $\%=\Sigma[200 \bullet($ Right - Left $) /($ Right + Left $)] / 8$

We calculated also for each locus EEG Shannon's [18] Entropy (h) of normalized PSD using Popovych's formulas [10,17]:

$\mathrm{hEEG}=-\left[\mathrm{PSD} \alpha \cdot \log _{2} \mathrm{PSD} \alpha+\mathrm{PSD} \beta \bullet \log _{2} \mathrm{PSD} \beta+\mathrm{PSD} \theta \bullet \log _{2} \mathrm{PSD} \theta+\mathrm{PSD} \delta \bullet \log _{2} \mathrm{PSD} \delta\right] / \log _{2} 4$

\section{RESULTS AND DISCUSSION}

Screening (Table 1) revealed the closest link between relative PSD of $\beta$-rhythm in locus T5 and virtual Chakras 1 and 6 Energy registered with filter (Figs. 1 and 2). 


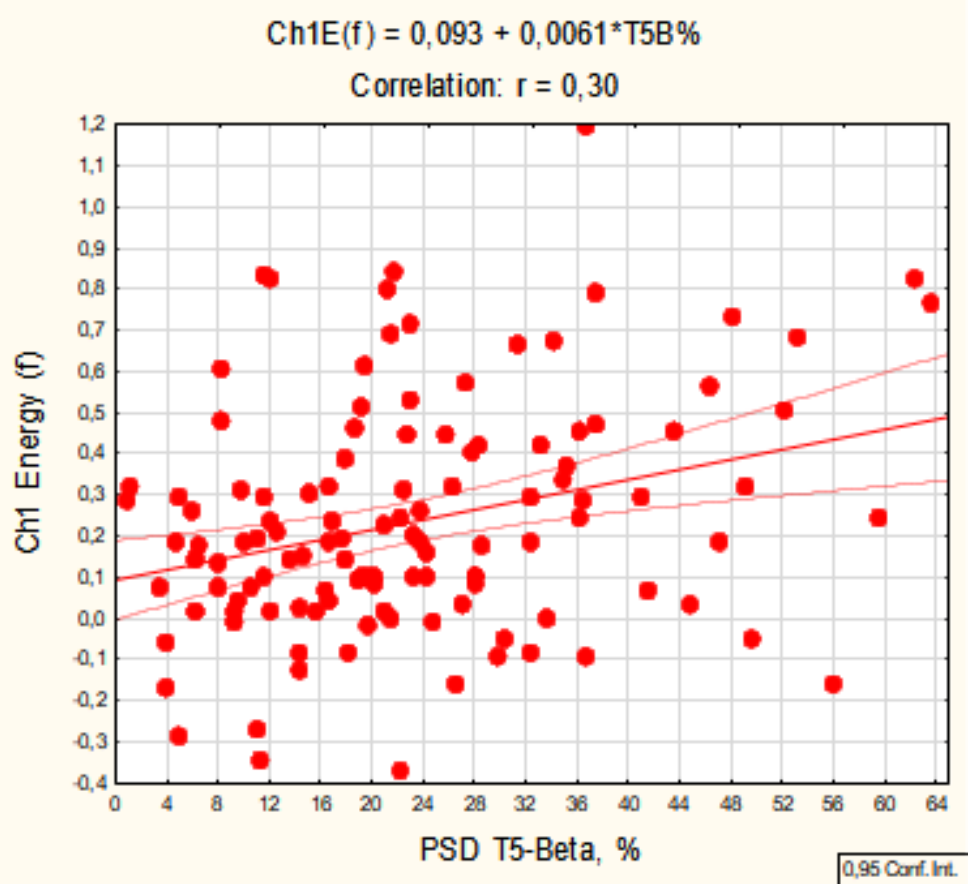

Fig. 1. Scatterplot of correlation between relative PSD of $\beta$-rhythm in locus T5 (Xline) and virtual Chakra 1 Energy (registration with filter) (Y-line)

$\operatorname{Ch} 6 \mathrm{E}(\mathrm{f})=-0,20+0,00616^{\star} \mathrm{T} 5 \mathrm{~B} \%$

Correlation: $r=0,30$

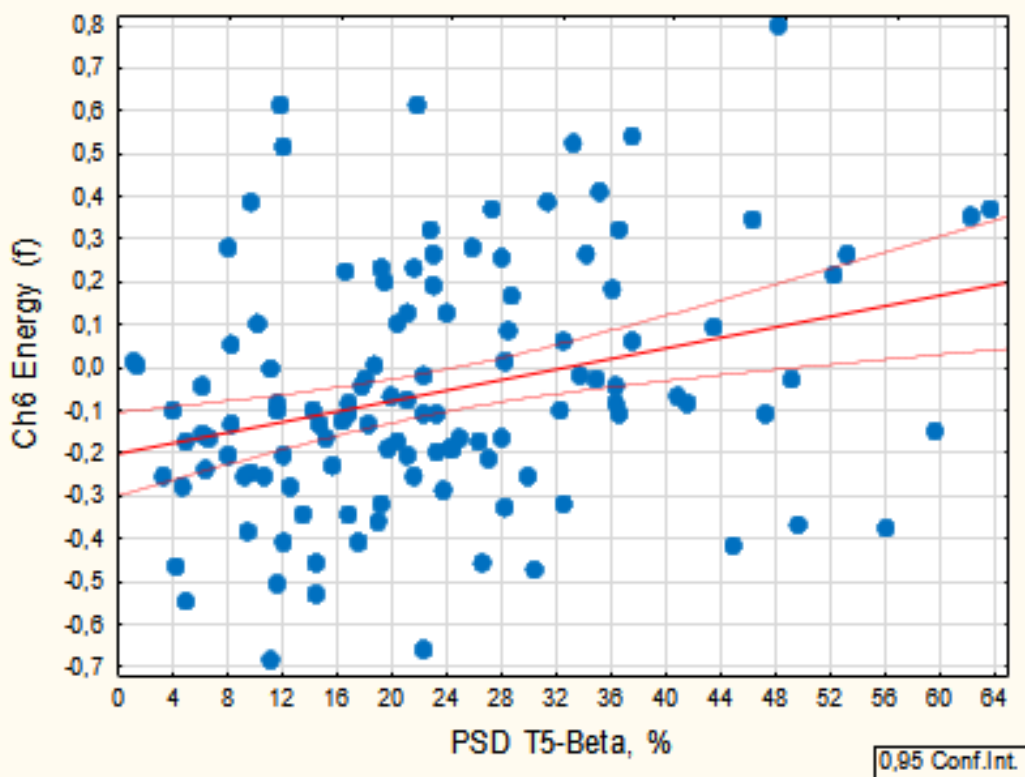

Fig. 2. Scatterplot of correlation between relative PSD of $\beta$-rhythm in locus T5 (Xline) and virtual Chakra 6 Energy (registration with filter) (Y-line)

The coefficients of canonical correlation between the EEG parameters and virtual Chakras Energy are in the interval $0,415 \div 0,564$ and $0,358 \div 0,528$ when registering without a filter and with a filter, respectively (Fig. 3). 


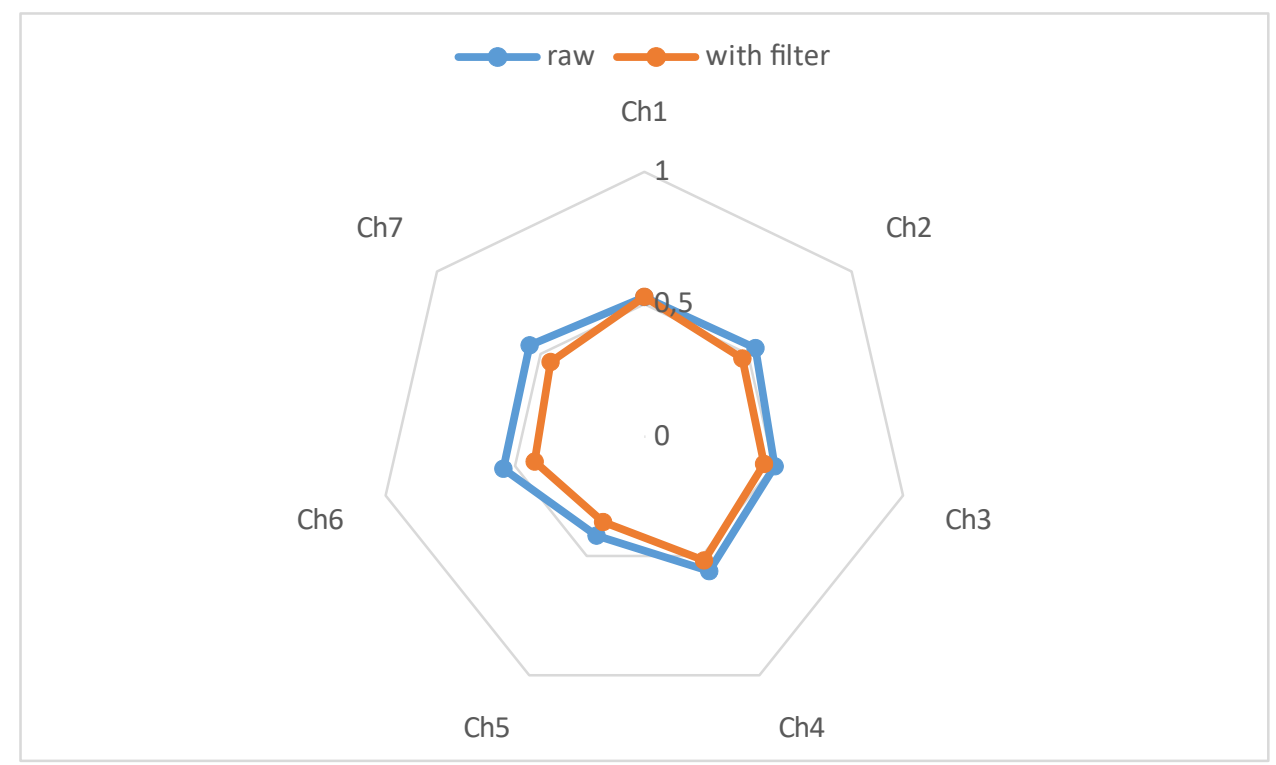

Fig. 3. Multiple correlation coefficients between EEG parameters and Energy of raw virtual Chakras and registered with filter

As we can see, the registration with the use of the filter reduces the strength of the connections of the EEG parameters with the Energy of the Chakras, mostly the sixth and seventh, except for the first Chakra. This is in perfect agreement with the classical ideas about the relationship of the former to the nervous system [9], as well as with the concept of Korotkov KG [11-13] that GDI, taken off without filter, characterizes the functional changes of organism, while taken with a filter characterizes organic changes. 
Table 1. Matrix of correlations between the virtual Chakras Energy and EEG parameters

\begin{tabular}{|c|c|c|c|c|c|c|c|c|c|c|c|c|c|c|}
\hline Variable & Ch1E & Ch1Ef & Ch2E & Ch2Ef & Ch3E & Ch3Ef & Ch4E & Ch4Ef & Ch5E & Ch5Ef & Ch6E & Ch6Ef & Ch7E & Ch7Ef \\
\hline DF & 0,16 & 0,27 & 0,11 & 0,16 & 0,11 & 0,24 & 0,13 & 0,14 & 0,10 & 0,18 & 0,14 & 0,22 & 0,15 & 0,22 \\
\hline AF & 0,24 & 0,22 & 0,24 & 0,22 & 0,17 & 0,16 & 0,19 & 0,21 & 0,14 & 0,12 & 0,19 & 0,14 & 0,19 & 0,19 \\
\hline LIA & 0,17 & 0,19 & 0,23 & 0,21 & 0,21 & 0,17 & 0,20 & 0,17 & 0,23 & 0,16 & 0,28 & 0,17 & 0,24 & 0,20 \\
\hline FP1H & 0,20 & 0,16 & 0,26 & 0,18 & 0,25 & 0,18 & 0,26 & 0,15 & 0,09 & 0,11 & 0,17 & 0,14 & 0,28 & 0,15 \\
\hline FP2H & 0,18 & 0,12 & 0,21 & 0,14 & 0,22 & 0,12 & 0,24 & 0,15 & 0,09 & 0,12 & 0,19 & 0,14 & 0,17 & 0,10 \\
\hline FP2B \% & 0,21 & 0,26 & 0,16 & 0,19 & 0,17 & 0,19 & 0,17 & 0,20 & 0,10 & 0,21 & 0,20 & 0,24 & 0,15 & 0,17 \\
\hline F3H & 0,21 & 0,19 & 0,19 & 0,16 & 0,23 & 0,15 & 0,25 & 0,14 & 0,18 & 0,23 & 0,24 & 0,22 & 0,17 & 0,16 \\
\hline F3B $\%$ & 0,19 & 0,22 & 0,15 & 0,16 & 0,12 & 0,18 & 0,13 & 0,18 & 0,14 & 0,19 & 0,23 & 0,23 & 0,14 & 0,17 \\
\hline F3T\% & 0,25 & 0,22 & 0,24 & 0,20 & 0,22 & 0,20 & 0,35 & 0,25 & 0,17 & 0,17 & 0,19 & 0,19 & 0,25 & 0,18 \\
\hline F3A & $-0,07$ & $-0,21$ & $-0,08$ & $-0,15$ & $-0,06$ & $-0,18$ & $-0,13$ & $-0,22$ & $-0,04$ & $-0,11$ & $-0,01$ & $-0,08$ & $-0,10$ & $-0,13$ \\
\hline $\mathrm{F} 4 \mathrm{H}$ & 0,25 & 0,19 & 0,29 & 0,23 & 0,28 & 0,21 & 0,28 & 0,18 & 0,15 & 0,18 & 0,24 & 0,22 & 0,28 & 0,25 \\
\hline F4T\% & 0,19 & 0,14 & 0,25 & 0,19 & 0,19 & 0,17 & 0,31 & 0,24 & 0,09 & 0,08 & 0,12 & 12 & 0,27 & 0,18 \\
\hline F7T\% & 0,22 & 0,13 & 0,28 & 0,18 & 0,24 & 0,10 & 0,33 & 0,23 & 0,06 & 0,01 & 11 & 07 & 28 & 0,15 \\
\hline F8H & 0,15 & 0,18 & 0,22 & 0,23 & 0,20 & 0,18 & 0,22 & 0,19 & 0,12 & 0,14 & 0,18 & 19 & 27 & 0,22 \\
\hline F8T\% & 0,21 & 0,13 & 0,23 & 0,16 & 0,16 & 0,10 & 0,26 & 0,19 & 0,09 & 0,05 & 0,14 & 09 & 28 & 0,15 \\
\hline T3H & 0,18 & 0,13 & 0,23 & 6 & 0,23 & 0,11 & 0,25 & 0 & 12 & 0,10 & 20 & 13 & 21 & 15 \\
\hline $\mathrm{T} 4 \mathrm{H}$ & 21 & 0,20 & 0,29 & 4 & 0,30 & 0,21 & 0,28 & 0,25 & 2 & 13 & 23 & 21 & 29 & 28 \\
\hline T4A & 5 & $-0,06$ & 0,06 & & 0,08 & $-0,03$ & 0,03 & $-0,08$ & 11 & 1 & 0,17 & 09 & 07 & 05 \\
\hline T4D & $-0,08$ & $-0,17$ & $-0,12$ & -0 & $-0,15$ & -0 & $-0,12$ & $-0,19$ & $-0,08$ & $-0,14$ & $-0,14$ & $-0,17$ & 13 & $-0,21$ \\
\hline С3T\% & 5 & & 0,20 & & 0,14 & & & & & & & 5 & 3 & 0,12 \\
\hline T5B\% & & & & & & & & & & 9 & 7 & 30 & 4 & 20 \\
\hline $\mathrm{T} 6 \mathrm{H}$ & & & & & & & & & & & & 21 & & 16 \\
\hline T6B & & 0,22 & & & & & & & & & 0,29 & 21 & 26 & 29 \\
\hline P3A\% & $-0,08$ & $-0,16$ & $-0,06$ & & $-0,06$ & & $-0,18$ & & $-0,13$ & $-0,15$ & $-0,10$ & $-0,13$ & $-0,06$ & $-0,12$ \\
\hline P4A & $-0,02$ & $-0,15$ & $-0,03$ & & $-0,03$ & $-0,12$ & $-0,14$ & $-0,23$ & $-0,02$ & $-0,11$ & $-0,00$ & $-0,10$ & $-0,04$ & $-0,12$ \\
\hline O2B $\%$ & 0,19 & 0,28 & 0,15 & 0,18 & 0,20 & 0,27 & 0,18 & 0,20 & 0,20 & 0,27 & 0,27 & 0,29 & 0,14 & 0,18 \\
\hline $\mathrm{O} 2 \mathrm{D}$ & $-0,21$ & $-0,17$ & $-0,21$ & $-0,15$ & $-0,24$ & $-0,15$ & $-0,21$ & $-0,15$ & $-0,07$ & $-0,12$ & $-0,14$ & $-0,13$ & $-0,17$ & $-0,15$ \\
\hline
\end{tabular}


Further, for canonical analysis, EEG parameters were combined with HRV parameters and hormones (see previous article [6]).

Interim results are shown in Tables 2 and 3 and Figures 4 and 5.

Table 2. Factor structure of EEG,HRV\&Endocrine and virtual Chakras (without filter) Energy Roots

\begin{tabular}{|c|c|}
\hline $\begin{array}{l}\text { Left set } \\
\text { EEG, HRV\&Hormones }\end{array}$ & $\mathbf{R}$ \\
\hline Entropy T4 & 0,506 \\
\hline Entropy F8 & 0,436 \\
\hline Entropy Fp1 & 0,416 \\
\hline Entropy F4 & 0,408 \\
\hline Entropy T6 & 0,361 \\
\hline Testosterone standard, Z & 0,356 \\
\hline F8-0 PSD, $\%$ & 0,353 \\
\hline Entropy Fp2 & 0,318 \\
\hline Laterality $\alpha, \mathrm{Hz}$ & 0,305 \\
\hline VLF, msec $^{2}$ & 0,302 \\
\hline F4- $\theta$ PSD, \% & 0,301 \\
\hline T6- $\beta$ PSD, $\mu \mathrm{V}^{2} / \mathrm{Hz}$ & 0,296 \\
\hline F7- $\theta$ PSD, $\%$ & 0,295 \\
\hline VLF+ULF, msec $^{2}$ & 0,287 \\
\hline Entropy T3 & 0,285 \\
\hline C3-0 PSD, \% & 0,250 \\
\hline Total Power HRV, msec ${ }^{2}$ & 0,233 \\
\hline O2- $\beta$ PSD, $\%$ & 0,196 \\
\hline T4- $\alpha$ PSD, $\mu V^{2} / H z$ & 0,181 \\
\hline F3- $\theta$ PSD, $\%$ & 0,179 \\
\hline Entropy F3 & 0,155 \\
\hline Frequency $\alpha, \mathrm{Hz}$ & 0,134 \\
\hline Heart Rate & 0,124 \\
\hline Amplitude Mode HRV, \% & 0,108 \\
\hline Vegetative Balance Index & 0,089 \\
\hline T5- $\beta$ PSD, $\%$ & 0,083 \\
\hline P3- $\alpha$ PSD, $\%$ & 0,081 \\
\hline Testosterone, nM/L & $-0,315$ \\
\hline LFnu, \% & $-0,229$ \\
\hline O2- $\delta$ PSD, $\mu V^{2} / H z$ & $-0,215$ \\
\hline $\begin{array}{l}\text { Right set } \\
\text { Chakras Energy }\end{array}$ & $\mathbf{R}$ \\
\hline $7 \mathrm{E}$ & 0,694 \\
\hline $2 \mathrm{E}$ & 0,600 \\
\hline $4 \mathrm{E}$ & 0,467 \\
\hline $3 \mathbf{E}$ & 0,446 \\
\hline $6 \mathrm{E}$ & 0,387 \\
\hline $1 \mathrm{E}$ & 0,282 \\
\hline $5 \mathrm{E}$ & 0,155 \\
\hline
\end{tabular}




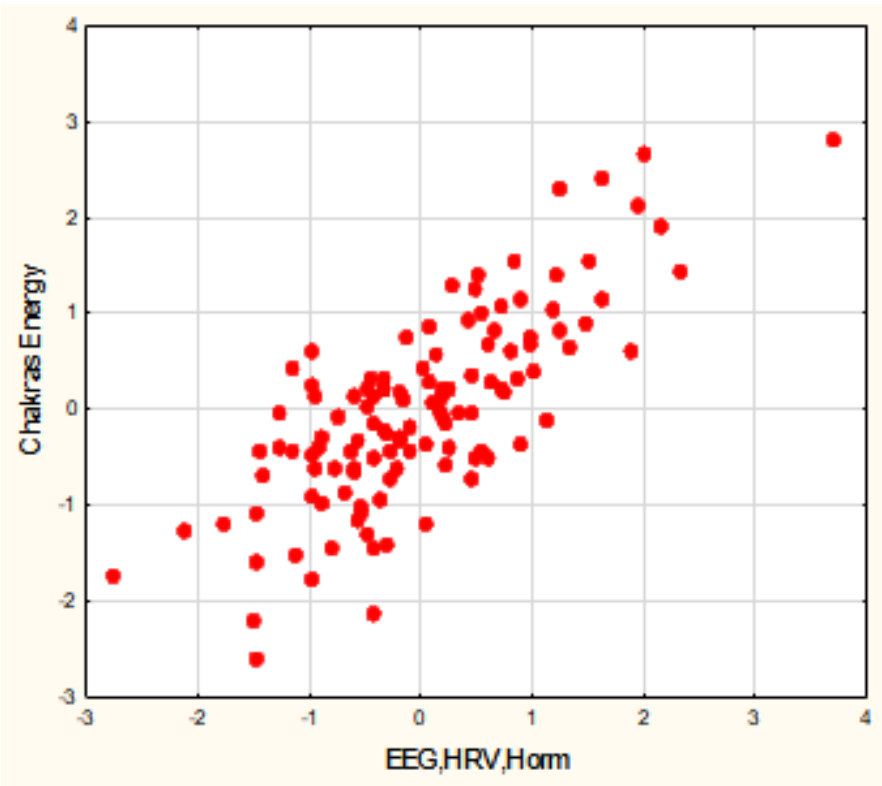

$\mathrm{R}=0,768 ; \mathrm{R}^{2}=0,590 ; \chi_{(245)}^{2}=313 ; \mathrm{p}=0,002 ; \Lambda$ Prime $=0,039$

Fig. 4. Scatterplot of canonical correlation between Neuro-endocrine parameters (X-line) and virtual Chakras Energy (registration without filter) (Y-line) 
Table 3. Factor structure of EEG,HRV\&Endocrine and virtual Chakras (with filter) Energy Roots

\begin{tabular}{|c|c|}
\hline $\begin{array}{l}\text { Left set } \\
\text { EEG, HRV\&Hormones }\end{array}$ & $\mathbf{R}$ \\
\hline Entropy T4 & 0,416 \\
\hline HF/TP & 0,237 \\
\hline Testosterone standard, Z & 0,235 \\
\hline Frequency $\alpha, \mathrm{Hz}$ & 0,216 \\
\hline F3-0 PSD, $\%$ & 0,209 \\
\hline T6- $\beta$ PSD, $\mu V^{2} / H z$ & 0,209 \\
\hline Heart Rate & 0,192 \\
\hline F3- $\beta$ PSD, $\%$ & 0,168 \\
\hline Laterality $\alpha, \mathbf{H z}$ & 0,159 \\
\hline Fp2- $\beta$ PSD, $\%$ & 0,127 \\
\hline Frequency $\delta, \mathrm{Hz}$ & 0,119 \\
\hline T5- $\beta$ PSD, $\%$ & 0,075 \\
\hline O1- $\beta$ PSD, $\%$ & 0,073 \\
\hline O2- $\beta$ PSD, $\%$ & 0,060 \\
\hline Total Power HRV, msec ${ }^{2}$ & 0,063 \\
\hline VLF, msec ${ }^{2}$ & 0,043 \\
\hline Testosterone, nM/L & $-0,468$ \\
\hline P4- $\alpha$ PSD, $\mu V^{2} / H z$ & $-0,196$ \\
\hline Amplitude Mode HRV, \% & $-0,189$ \\
\hline T4- $\delta$ PSD, $\mu V^{2} / H z$ & $-0,183$ \\
\hline P3- $\alpha$ PSD, $\%$ & $-0,159$ \\
\hline Vegetative Balance Index & $-0,145$ \\
\hline LFnu, \% & $-0,143$ \\
\hline F3- $\alpha$ PSD, $\mu V^{2} / H z$ & $-0,120$ \\
\hline Cortisol, $\mathrm{nM} / \mathrm{L}$ & $-0,106$ \\
\hline $\begin{array}{l}\text { Right set } \\
\text { Chakras Energy }\end{array}$ & $\mathbf{R}$ \\
\hline $4 \mathrm{E} \mathrm{f}$ & 0,633 \\
\hline $7 \mathbf{E ~ f}$ & 0,586 \\
\hline $2 \mathrm{Ef}$ & 0,530 \\
\hline $1 \mathrm{Ef}$ & 0,296 \\
\hline $3 \mathrm{Ef}$ & 0,283 \\
\hline $6 \mathrm{E} \mathrm{f}$ & 0,208 \\
\hline $5 \mathrm{Ef}$ & 0,007 \\
\hline
\end{tabular}




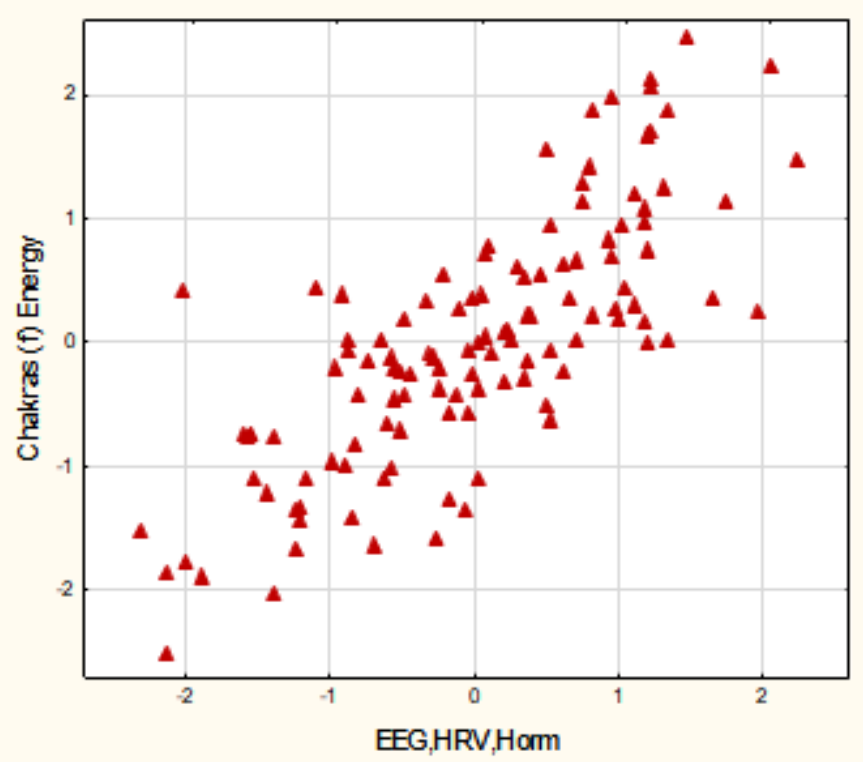

$\mathrm{R}=0,772 ; \mathrm{R}^{2}=0,596 ; \chi^{2}{ }_{(210)}=283 ; \mathrm{p}=0,0006 ; \Lambda$ Prime $=0,057$

Fig. 5. Scatterplot of canonical correlation between Neuro-endocrine parameters (X-line) and virtual Chakras Energy (registration with filter) (Y-line)

In the end, it was found (Table 4) that the prominent places in the factor structure of the root of Chakra Energies are occupied by the seventh, second and fourth Chakras, which are responsible for: the pineal gland, right brain, upper brain, right eye; testes/ovaries; and heart, circulation, vagal nerve, respectively [9]. On the other hand, the factor structure of the neuroendocrine root is represented primarily by Entropies and PSD right-handed (paired) loci, as well as testosterone. 
Table 4. Factor structure of EEG,HRV\&Endocrine and virtual Chakras Energy Roots

\begin{tabular}{|c|c|}
\hline EEG, HRV\&Hormones & $\mathbf{R}$ \\
\hline Entropy T4 & $-0,460$ \\
\hline Testosterone standard, $\mathrm{Z}$ & $-0,343$ \\
\hline F7- $\theta$ PSD, $\%$ & $-0,320$ \\
\hline Entropy F8 & $-0,318$ \\
\hline F8- $\theta$ PSD, $\%$ & $-0,315$ \\
\hline T6- $\beta$ PSD, $\mu V^{2} / H z$ & $-0,298$ \\
\hline F4- $\theta$ PSD, $\%$ & $-0,283$ \\
\hline Laterality $\alpha, \mathbf{H z}$ & $-0,280$ \\
\hline Entropy F4 & $-0,277$ \\
\hline Entropy T6 & $-0,266$ \\
\hline C3-0 PSD, $\%$ & $-0,233$ \\
\hline Entropy T3 & $-0,230$ \\
\hline F3- $\beta$ PSD, $\%$ & $-0,226$ \\
\hline Frequency $\alpha, \mathrm{Hz}$ & $-0,220$ \\
\hline Heart Rate & $-0,213$ \\
\hline Entropy Fp1 & $-0,211$ \\
\hline HF/TP & $-0,189$ \\
\hline Entropy Fp2 & $-0,172$ \\
\hline T4- $\alpha$ PSD, $\mu V^{2} / H z$ & $-0,165$ \\
\hline Fp2- $\beta$ PSD, $\%$ & $-0,161$ \\
\hline F3- $\theta$ PSD, $\%$ & $-0,154$ \\
\hline Frequency $\delta, \mathrm{Hz}$ & $-0,122$ \\
\hline O2- $\beta$ PSD, $\%$ & $-0,111$ \\
\hline O1- $\beta$ PSD, $\%$ & $-0,106$ \\
\hline VLF, msec ${ }^{2}$ & $-0,108$ \\
\hline Total Power HRV, msec ${ }^{2}$ & $-0,088$ \\
\hline T5- $\beta$ PSD, $\%$ & $-0,078$ \\
\hline Entropy F3 & $-0,055$ \\
\hline Testosterone, nM/L & 0,398 \\
\hline T4- $\delta$ PSD, $\mu V^{2} / \mathbf{H z}$ & 0,217 \\
\hline O2- $\delta$ PSD, $\mu V^{2} / H z$ & 0,136 \\
\hline LFnu, \% & 0,124 \\
\hline P4- $\alpha$ PSD, $\mu V^{2} / H z$ & 0,094 \\
\hline Cortisol, nM/L & 0,053 \\
\hline Amplitude Mode HRV, \% & 0,017 \\
\hline Chakras Energy & $\mathbf{R}$ \\
\hline $7 \mathbf{E}$ & $-0,583$ \\
\hline $7 \mathrm{E} \mathrm{f}$ & $-0,578$ \\
\hline $2 \mathrm{E}$ & $-0,531$ \\
\hline $2 \mathrm{E} \mathrm{f}$ & $-0,522$ \\
\hline $4 \mathrm{E} \mathrm{f}$ & $-0,544$ \\
\hline $4 \mathrm{E}$ & $-0,487$ \\
\hline $3 \mathbf{E}$ & $-0,333$ \\
\hline $3 \mathrm{EH}$ & $-0,286$ \\
\hline $6 \mathrm{E}$ & $-0,306$ \\
\hline $6 \mathrm{Ef}$ & $-0,274$ \\
\hline $1 \mathrm{E} \mathrm{f}$ & $-0,283$ \\
\hline $1 \mathrm{E}$ & $-0,259$ \\
\hline $5 \mathrm{E}$ & $-0,111$ \\
\hline $5 \mathrm{E} \mathbf{f}$ & $-0,058$ \\
\hline
\end{tabular}




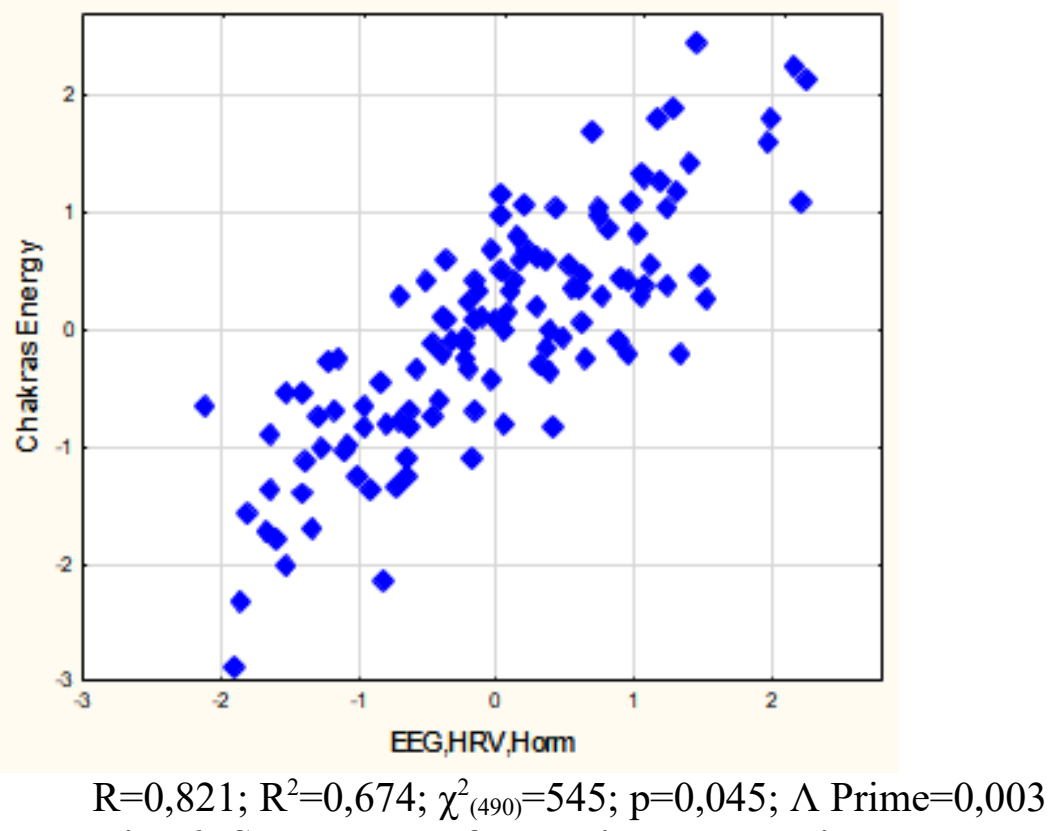

Fig. 6. Scatterplot of canonical correlation between Neuro-endocrine parameters (X-line) and virtual Chakras Energy (Y-line)

Another basic characteristic of virtual Chakras is their Asymmetry. This is consistent with the position of the existence of morpho-functional asymmetry of many, if not all, paired organs or their halves, including the hemispheres of the brain [7,8,14-16].

Screening revealed a number of significant correlations, the strongest of which are shown in Figures 7 and 8.

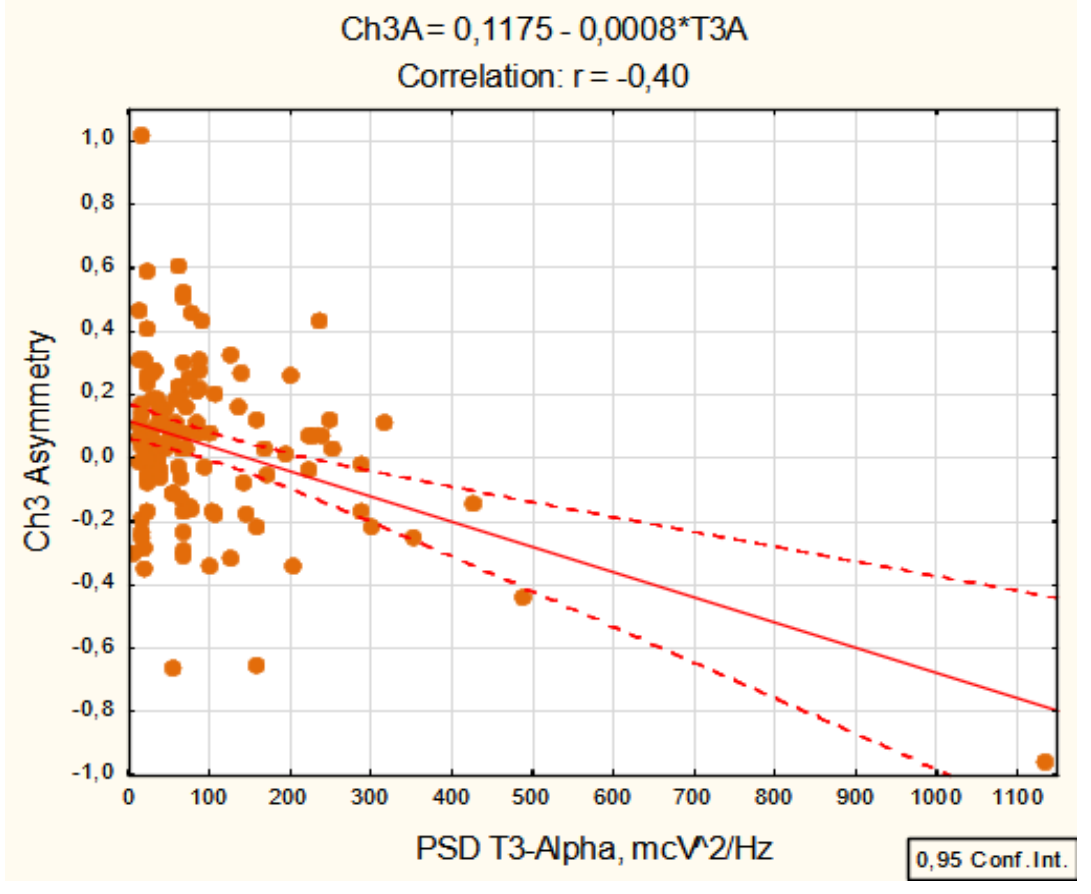

Fig. 7. Scatterplot of correlation between PSD of $\alpha$-rhythm in locus T3 (X-line) and virtual Chakra 3 Asymmetry (Y-line) 


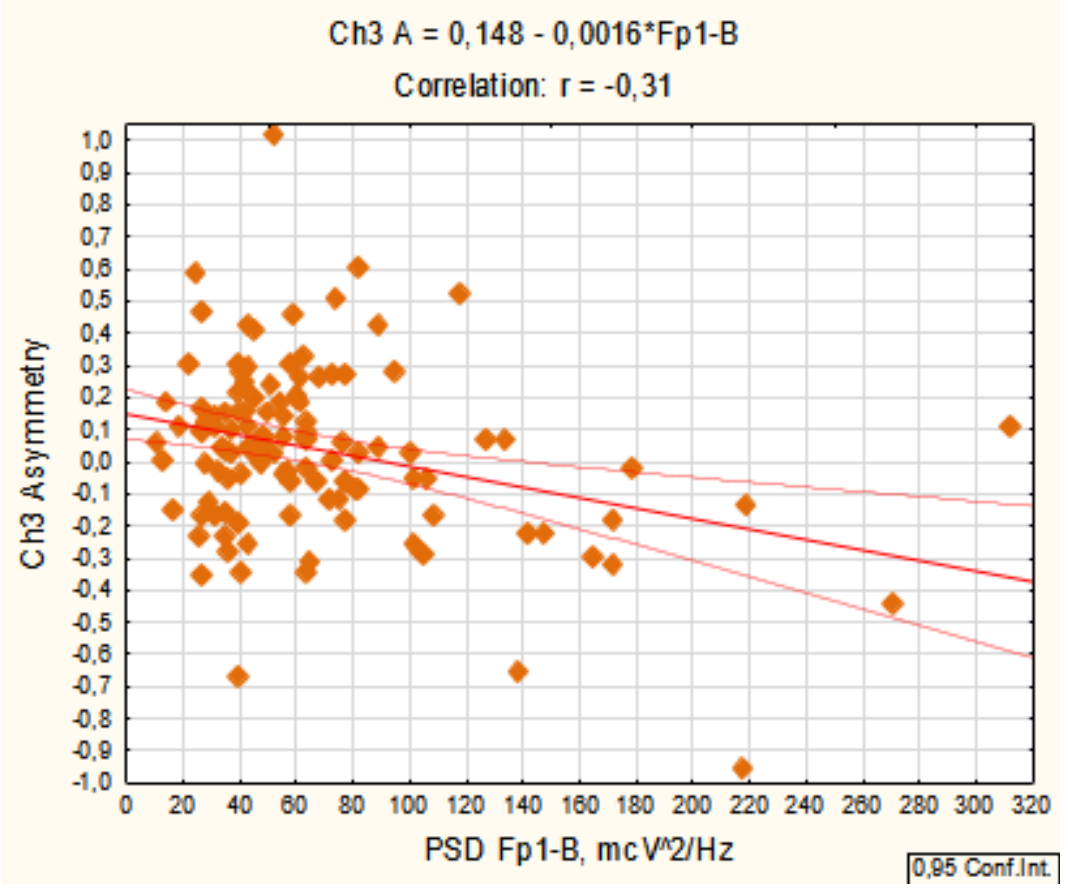

Fig. 8. Scatterplot of correlation between PSD of $\beta$-rhythm in locus Fp1 (X-line) and virtual Chakra 3 Asymmetry (Y-line)

Interestingly, the effect of the polyethylene filter on the strength of the bonds with the EEG parameters of the Asymmetry of the Chakras was much more noticeable compared to their Energy. This is especially true of the Asymmetry of the third and seventh Chakras, while the EEG connections of the sixth Chakra remain stable (Fig. 9).

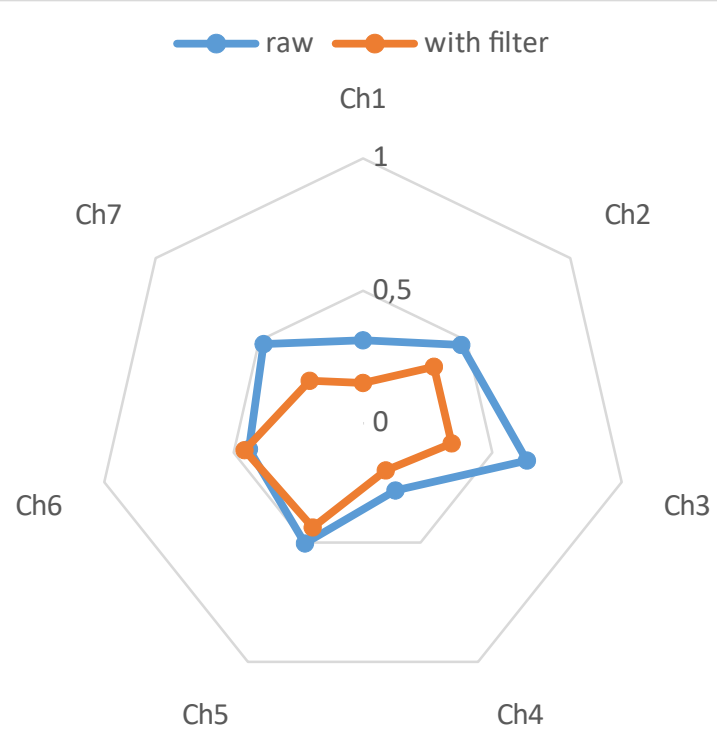

Fig. 9. Multiple correlation coefficients between EEG parameters and Asymmetry of raw virtual Chakras and registered with filter

In general, the canonical correlation between EEG parameters and the asymmetry of virtual chakras is stated as strong (Table 5 and Fig. 10). 
Table 5. Factor structure of EEG and virtual Chakras Asymmetry Roots

\begin{tabular}{|c|c|}
\hline $\begin{array}{l}\text { Left set } \\
\text { EEG, HRV\&Hormones }\end{array}$ & $\mathbf{R}$ \\
\hline T5- $\theta$ PSD, $\mu V^{2} / H z$ & $-0,488$ \\
\hline Fp1- $\theta$ PSD, $\mu V^{2} / H z$ & $-0,471$ \\
\hline T4- $\alpha$ PSD, $\mu V^{2} / H z$ & $-0,436$ \\
\hline Fp2- $\alpha$ PSD, $\mu V^{2} / H z$ & $-0,432$ \\
\hline F7- $\alpha$ PSD, $\mu V^{2} / H z$ & $-0,430$ \\
\hline C3- $\theta$ PSD, $\mu V^{2} / H z$ & $-0,415$ \\
\hline T3- $\alpha$ PSD, $\mu V^{2} / H z$ & $-\mathbf{0 , 4 0 7}$ \\
\hline O1- $\theta$ PSD, $\mu V^{2} / H z$ & $-0,404$ \\
\hline Index $\beta, \%$ & $-0,400$ \\
\hline P3- $\theta$ PSD, $\mu V^{2} / H z$ & $-0,337$ \\
\hline F4- $\delta$ PSD, $\mu V^{2} / H z$ & $-0,329$ \\
\hline T5- $\delta$ PSD, $\mu V^{2} / H z$ & $-0,314$ \\
\hline T5- $\delta$ PSD, $\%$ & $-0,245$ \\
\hline O1- $\alpha$ PSD, $\mu V^{2} / H z$ & $-0,313$ \\
\hline F7- $\theta$ PSD, $\mu V^{2} / H z$ & $-0,291$ \\
\hline C4- $\delta$ PSD, $\mu V^{2} / H z$ & $-0,289$ \\
\hline Fp2- $\theta$ PSD, $\mu V^{2} / H z$ & $-0,275$ \\
\hline Fp1- $\beta$ PSD, $\mu V^{2} / H z$ & $-0,274$ \\
\hline T5- $\alpha$ PSD, $\mu V^{2} / H z$ & $-0,245$ \\
\hline F3- $\alpha$ PSD, $\mu V^{2} / H z$ & $-0,240$ \\
\hline C4- $\alpha$ PSD, $\mu V^{2} / H z$ & $-0,212$ \\
\hline T6- $\beta$ PSD, $\mu V^{2} / H z$ & $-0,179$ \\
\hline Frequency $\beta, \mathrm{Hz}$ & 0,397 \\
\hline Fp2- $\beta$ PSD, $\%$ & 0,289 \\
\hline Frequency $\boldsymbol{\theta}, \mathrm{Hz}$ & 0,282 \\
\hline F3- $\beta$ PSD, $\%$ & 0,278 \\
\hline Laterality $\delta, \%$ & 0,171 \\
\hline P3- $\beta$ PSD, $\%$ & 0,120 \\
\hline O2- $\beta$ PSD, $\%$ & 0,119 \\
\hline Frequency $\delta, \mathrm{Hz}$ & 0,091 \\
\hline $\begin{array}{l}\text { Right set } \\
\text { Chakras Asymmetry }\end{array}$ & $\mathbf{R}$ \\
\hline $3 \mathbf{A}$ & 0,519 \\
\hline $5 \mathrm{~A} \mathrm{f}$ & 0,515 \\
\hline $2 \mathrm{~A}$ & 0,488 \\
\hline $6 \mathrm{Af}$ & 0,421 \\
\hline $3 \mathrm{Af}$ & 0,375 \\
\hline $2 \mathrm{Af}$ & 0,361 \\
\hline $7 \mathrm{~A}$ & 0,343 \\
\hline $7 \mathrm{~A} \mathrm{f}$ & 0,260 \\
\hline $4 \mathrm{~A}$ & $-0,162$ \\
\hline $1 \mathrm{~A}$ & $-0,147$ \\
\hline $6 \mathrm{~A}$ & $-0,053$ \\
\hline $5 \mathrm{~A}$ & $-0,048$ \\
\hline $1 \mathrm{~A} \mathrm{f}$ & $-0,037$ \\
\hline
\end{tabular}




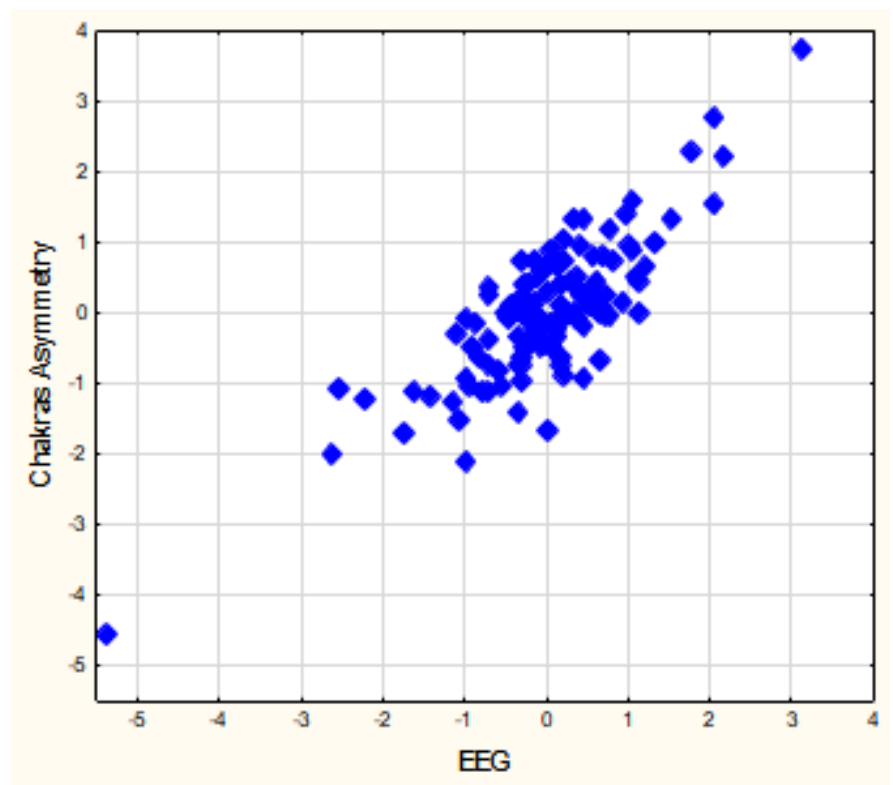

\section{$\mathrm{R}=0,820 ; \mathrm{R}^{2}=0,673 ; \chi_{(468)}^{2}=519 ; \mathrm{p}=0,054 ; \Lambda$ Prime $=0,004$ \\ Fig. 10. Scatterplot of canonical correlation between EEG parameters (X-line) and virtual Chakras Asymmetry(Y-line)}

\section{CONCLUSION}

We have been shown that exist strong canonical correlation between parameters of GDV and principal neuroendocrine factors of adaptation [1,6], EEG [2,6] as well as parameters of leukocytogram [5], immunity [3] and phagocytosis [4].

The above data, taken together with the previous ones, state that between parameters of neuro-endocrine-immune complex and GDV exist strong canonical correlation suggesting suitability of the latter method.

However, mathematics, despite the status of the queen of sciences, is unable to solve the problem of localizing the parameters of the chakras and neuro-endocrine-immune complex on the abscissa as the cause, or on the ordinate as a consequence ...

\section{ACKNOWLEDGMENT}

We express sincere gratitude to administration JSC "Truskavets'kurort" for help in carrying out EEG\&HRV registration. Special thanks to the volunteers.

\section{ACCORDANCE TO ETHICS STANDARDS}

Tests in volunteers are conducted in accordance with positions of Helsinki Declaration 1975, revised and complemented in 2002, and directive of National Committee on ethics of scientific researches. During realization of tests from all participants the informed consent is got and used all measures for providing of anonymity of participants.

\section{REFERENCES}

1. Babelyuk VE, Gozhenko AI, Dubkova GI, Babelyuk NV, Zukow W, Kovbasnyuk MM, Popovych IL. Causal relationships between the parameters of gas discharge visualization and principal neuroendocrine factors of adaptation. Journal of Physical Education and Sport. 2017; 17(2): 624-637.

2. Babelyuk VYe, Popadynets' OO, Dubkova GI, Zukow W, Muszkieta R, Gozhenko OA, Popovych IL. Entropy of gas-discharge image correlates with the entropies of EEG, immunocytogram and leukocytogram but not HRV. Pedagogy and Psychology of Sport. 2020; 6(2): 30-39. 
3. Babelyuk VYe, Gozhenko AI, Dubkova GI, Zukow W, Hubyts'kyi VY, Ruzhylo SV, Fedyayeva SI, Kovalchuk HY, Popovych IL. Causal relationships between the parameters of gas discharge visualization and immunity. Pedagogy and Psychology of Sport. 2021; 7(1): 115-134.

4. Babelyuk VY, GozhenkoAI, Dubkova GI, Babelyuk NV, Zukow W, Kindzer BM, Kovbasnyuk MM, Popovych IL. Causal relationships between the parameters of gas discharge visualization and phagocytosis. Journal of Education, Health and Sport. 2021; 11(6): 268-276.

5. Babelyuk VY, Tserkovnyuk RG, Ruzhylo SV, Dubkova GI, Babelyuk NV, Zukow W, Popovych IL. Causal relationships between the parameters of gas discharge visualization and leukocytogram. Journal of Education, Health and Sport. 2021; 11(7): 258-269.

6. Babelyuk VY, Tserkovniuk RG, Babelyuk NV, Źukow X, Ruzhylo SV, Dubkova GI, Korolyshyn TA, Hubyts'kyi VY, Kikhtan VV, Gozhenko AI, Popovych IL. The parameters of gas discharge visualization (biophotonics) correlated with parameters of acupuncture points, EEG, HRV and hormones. Journal of Education, Health and Sport. 2021; 11(12): 359-373.

7. Balle M, Bornas X, Tortella-Feliu M, Llabrés J, Morillas-Romero A, Aguayo-Siquier B, Gelabert JM. Resting parietal EEG asymmetry and cardiac vagal tone predict attentional control. Biol Psychol. 2013; 93(2): 257-261.

8. Barylyak LG, Kruhliy YuZ, Zukow W, Yanchiy OR, Popovych IL. Indicators, distinctive for women with different ovarian status and different responses streslimiting effect of bioactive water Naftussya spa Truskavets'. Journal of Education, Health and Sport. 2015; 5(3): 247-258.

9. $\quad$ Chase CR. The Geometry of Emotions: Using Chakra Acupuncture and 5-Phase Theory to Describe Personality Archetypes for Clinical Use. Med Acupunct. 2018; 30(4): 167-178.

10. Gozhenko AI, Korda MM, Popadynets' OO, Popovych IL. Entropy, Harmony, Synchronization and Their Neuro-endocrine-immune Correlates [in Ukrainian]. Odesa. Feniks; 2021: 232.

11. Korotkov KG. Basics GDV Bioelectrography [in Russian]. SPb. SPbGITMO(TU); 2001: 360.

12. Korotkov KG. Principles of Analysis in GDV Bioelectrography [in Russian]. SPb. Renome; 2007: 286.

13. Korotkov KG. Energy Fields Electrophotonic Analysis in Humans and Nature. Second updated edition. Translated from Russian by the author. Edited by Berney Williams and Lutz Rabe. 2014: 233.

14. Kruhliy YuZ Features of the influence of bioactive water Naftussya on the level of chronic stress in women with different ovarian status. Medical hydrology and rehabilitation. 2010; 8(4): 62-68.

15. Kruhliy YuZ Neuroendocrine support of polyvariant effects of Naftussya bioactive water on the level of chronic stress in women with different ovarian status. Medical hydrology and rehabilitation. 2012; 10(2): 92-96.

16. Miskovic V, Schmidt LA. Frontal brain electrical asymmetry and cardiac vagal tone predict biased attention to social threat. Int J Psychophysiol. 2010; 75(3): 332-338.

17. Popadynets' OO, Gozhenko AI, Zukow W, Popovych IL. Relationships between the entropies of EEG, HRV, immunocytogram and leukocytogram. Journal of Education, Health and Sport. 2019; 9(5): 651-666.

18. Shannon CE. Works on the theory of informatics and cybernetics [transl. from English to Russian]. Moskva. Inostrannaya literatura; 1963: 329. 